\title{
Long-Term Intravenous Infusion of Antiarrhythmic Drugs Using a Totally Implanted Drug Delivery System
}

\author{
JEFFREY L. ANDERSON, MD, FACC* \\ ELTON M. TUCKER ${ }^{\dagger}$ \\ STANISLAW PASYK, MD \\ EUGENE PATTERSON, PhD \\ ARTHUR B. SIMON, MD, FACC \\ WILLIAM E. BURMEISTER \\ BENEDICT R. LUCCHESI, PhD, MD \\ BERTRAM PITT, MD, FACC \\ with the technical assistance of \\ RICHARD P. DONAHUE \\ MARILYN E. CONLON, MA \\ Ann Arbor, Michigan
}

\begin{abstract}
In vitro and in vivo testing was performed to establish the feasibility of a totally implantable pump system to deliver antiarrhythmic agents. In vitro flow characteristics suggested predictable day to day delivery with acceplably small variations in flow with changes in reservoir volume or temperature. During 3 months of in vitro testing, procainamide and bretyllum were found sultable for long-term delivery. Delivery of lidocaine was limited by high viscosity and corrosion of steel elements within the pump. The pump was implanted in a subcutaneous pocket in four dogs. Procainamide $(0.5 \mathrm{~g} / \mathrm{ml})$, dellvered at $4 \mathrm{ml} /$ day $(70 \mathrm{mg} / \mathrm{kg}$ body weight per day), provided a mean steady state drug concentration of $5.3 \mu \mathrm{g} / \mathrm{ml}$. Bretyllum $(50 \mathrm{mg} / \mathrm{ml})$, delivered at $8 \mathrm{ml} /$ day $(13 \mathrm{mg} / \mathrm{kg}$ per day ), provided a steady state concentration of $0.8 \mu \mathrm{g} / \mathrm{ml}$ (range 0.4 to 1.4 ). Long-term intravenous administration of therapeutic doses of bretylium and procainamide with this delivery system has been demonstrated in dogs and appears to be feasible in human subjects.
\end{abstract}

Successful antiarrhythmic therapy depends on the maintenance of therapeutic concentrations of a drug in blood and myocardium., However, long-term oral treatment with several antiarrhythmic agents is limited by unfavorable pharmacodynamics. Bretylium, for example, is poorly absorbed when administered orally. ${ }^{3,4}$ Lidocaine is subject to extensive hepatic first pass degradation, limiting its use to intravenous administration. ${ }^{2}$ Procainamide has a short plasma half-life (about 3 hours), requiring frequent dosing for maintenance of therapeutic concentrations. ${ }^{2}$ Because of these considerations, the effective use of these and similar agents has been limited primarily to hospitalized patients receiving intravenous medication under careful monitoring in the intensive care unit.

Recently, an implantable drug delivery system (Infusaid Corporation, Sharon, Massachusetts) has become available for long-term delivery of selected drugs. ${ }^{5-8}$ Recent applications have included administration of such diverse drugs as heparin, insulin and cancer chemotherapeutic agents. Use of the pump in patients for up to 4 years has now been achieved. The Infusaid ${ }^{\circledast}$ pump consists of a hollow titanium disk separated into two compartments by a metal bellows (Fig. 1). The pump is powered by the vapor pressure of a two phase charging fluid in equilibrium with its liquid phase at body temperature. The pressure exerted on the bellows forces the drug from the reservoir at a constant rate through a filter and fine bore catheter into a delivery site (that is, peripheral vein). The drug reservoir is refilled percutaneously through a port by means of a hypodermic syringe. We sought to establish the feasibility of long-term parenteral delivery of selected antiarrhythmic drugs using this totally implantable pump system.

\section{Methods}

The study included in vitro and in vivo testing of the drug delivery system. Antiarrhythmic agents selected for testing included lidocaine, procainamide and bretylium tosylate. 
FIGURE 1. Schematic diagram of metal bellows pump system (Infusaid , model 100). Courtesy Infusaid Corporation, Sharon, Massachusetts.

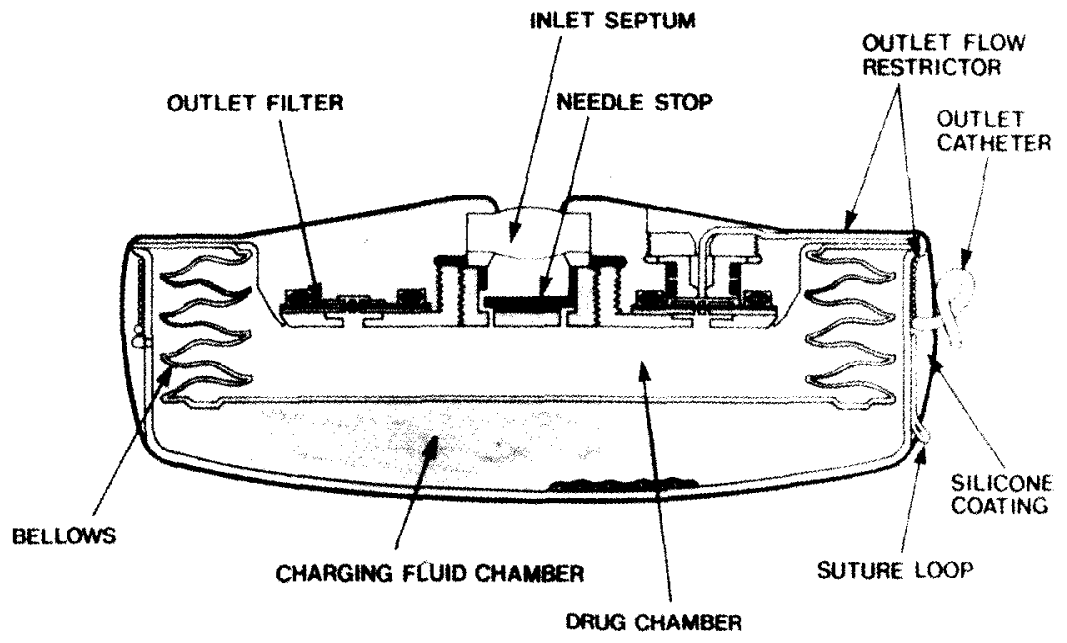

Hubner point needle inserted through the skin and pumpinlet septum. Residual pump volume was measured and the pump filled with drug.

Plasma blood concentrations: Blood samples were withdrawn from a forearm vein generally at $1,2,8,24$ and 48 hours; every 1 to 2 days during the testing period (usually 2 weeks); and on washout days 1 and 2 after replacement of drug with normal saline solution. Plasma was assayed for lidocaine and procainamide in the clinical pharmacology laboratory with use of standard methods. Bretylium was assayed using a method developed in our institution. ${ }^{9}$

\section{Results}

In vitro testing: Pump flow was predictably influenced by bath temperature and variations in spring force of the metal bellows as the reservoir moved from full to empty. During in vitro testing, flow rose linearly by 6 percent per degree Fahrenheit elevation in temperature about the physiologic range $\left(95\right.$ to $\left.103^{\circ} \mathrm{F}\right)\left(35\right.$ to $\left.39.4^{\circ} \mathrm{C}\right)$. In vivo flow depends on body temperature, which is closely regulated. Over the useful range of reservoir volumes, flow variability was consistently \pm 3 to 5 percent (coefficient of variation) about the mid range volume. A typical result of in vitro testing over 22 days (pump $\mathrm{S} / \mathrm{N} 029$ ) consisted of a mean ( \pm standard deviation) delivery rate of $6.15( \pm 0.34) \mathrm{ml} /$ day (20 determinations). Overfilling, associated with increased output, and reservoir depletion below residual volume, associated with decreased output, were easily avoided.

\section{TABLE I}

Design and Performance Characteristics of Infusald Pump Model 100

\begin{tabular}{ll}
\hline \multicolumn{1}{c}{ Feature } & \\
\hline $\begin{array}{l}\text { Reservoir volume } \\
(\mathrm{ml})\end{array}$ & $50(47$, useful volume) \\
$\begin{array}{l}\text { Flow rate (ml } \mathrm{H}_{2} \mathrm{O} / \\
\text { day) }\end{array}$ & $\begin{array}{c}\text { Adjusted at factory to desired value } \\
\text { (typically set at } 6 \text { to } 12)\end{array}$ \\
$\begin{array}{l}\text { Output pressure } \\
\text { (mm Hg) }\end{array}$ & 450 at $37^{\circ} \mathrm{C}$ \\
Diameter $(\mathrm{mm})$ & 86 \\
Thickness $(\mathrm{mm})$ & 27 \\
Empty weight $(\mathrm{g})$ & 180 \\
Materials & Drug in contact with titanium, stainless \\
& steel, polypropylene, silicone rubber \\
& and a membrane filter \\
\hline
\end{tabular}




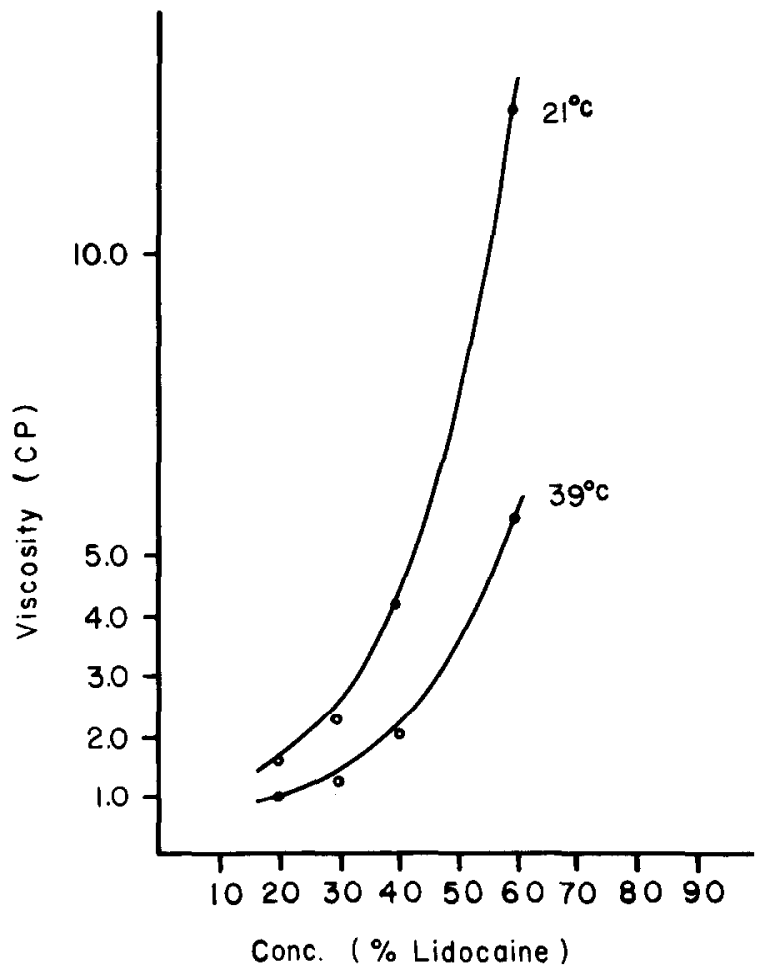

FIGURE 2. Viscosity of lidocaine solutions (in centipoise [CP]) as a function of concentration (Conc.) (percent $=\mathrm{g} / \mathrm{ml} \times 100$ ) at two temperatures bounding the physiologic range.

During 3 months of in vitro testing, the pump delivered procainamide and bretylium reliably with continuous capillary flow ( 4 and $8 \mathrm{ml} /$ day, respectively) and normal filter function. No evidence of element corrosion or reservoir precipitate was. noted.

In contrast, lidocaine caused galvanic corrosion of stainless steel elements within the pump. An additional problem with lidocaine is shown in Figure 2. Over the concentration range of 35 to 70 percent $(\mathrm{g} / \mathrm{ml})$, calculated to result in therapeutic drug delivery, a steep rise in viscosity occurred and samples acted as saturated solutions.

In vivo studies: The results of in vivo studies for the three drugs are presented in Figure 3. Therapeutic ranges in patients are overlaid for comparison.

Average systemic concentrations of lidocaine of only 0.1 $\mu \mathrm{g} / \mathrm{ml}$ were achieved. The range of individual steady state determinations during lidocaine infusions was 0 to $24 \mathrm{ng} / \mathrm{ml}$ (mean $6 \mathrm{ng} / \mathrm{ml}, \mathrm{n}=7$ ) for the 4 percent solution and 27 to 139 $\mathrm{ng} / \mathrm{ml}$ (mean $82 \mathrm{ng} / \mathrm{ml}, \mathrm{n}=13$ ) for solutions of 35 to 70 percent. Simultaneous concentrations of the lidocaine metabolites glycinexylidide and monethylglycinexylidide were also low (mean value 32 and $16 \mathrm{ng} / \mathrm{ml}$, respectively; 35 to 70 percent lidocaine solutions). The low lidocaine concentrations may be ascribed, at least in part, to high drug viscosity and adverse pump-drug interactions which were noted during in vitro testing.

Results with procainamide and bretylium were more favorable. A commercial preparation of procainamide $(0.5 \mathrm{~g} / \mathrm{ml})$ infused at $4 \mathrm{ml} /$ day allowed delivery of $70 \mathrm{mg} / \mathrm{kg}$ per day. Steady state concentrations of procainamide within the therapeutic range were attained, with a mean plasma concentration of $5.3 \mu \mathrm{g} / \mathrm{ml}$. Steady state concentrations were

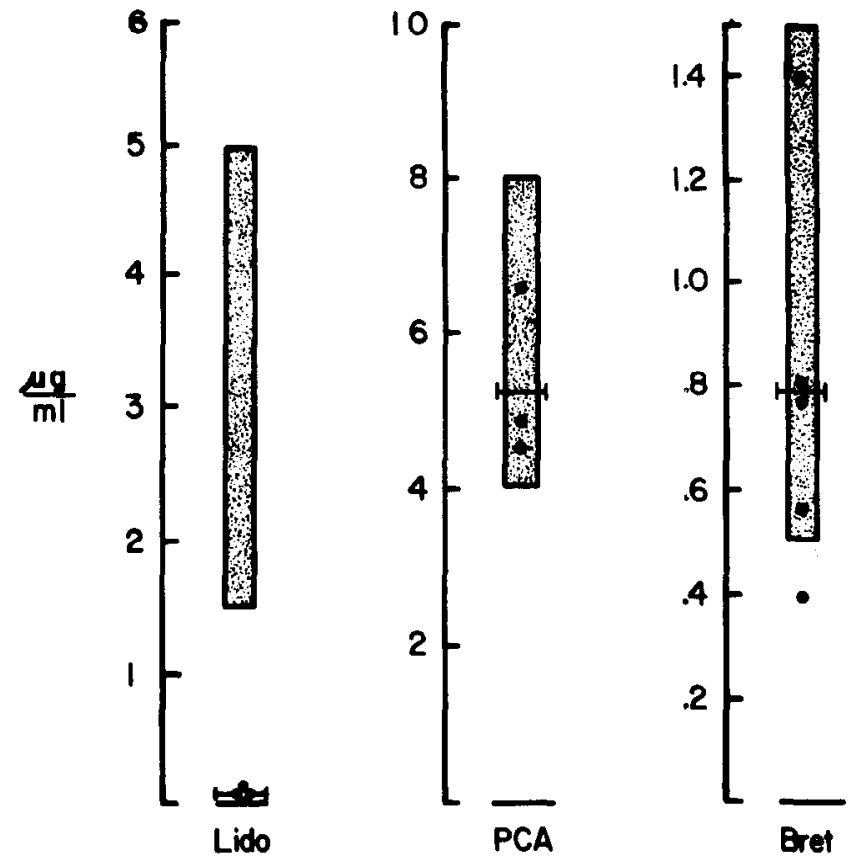

FIGURE 3. Average systemic concentrations attained during in vivo testing of three antiarrhythmic drugs: lidocaine (Lido), procainamide (PCA) and bretylium tosylate (Bret). See text for details. The therapeutic ranges for patients of these drugs are overlaid in the shaded bars for comparison. The bars indicate the mean concentration attained for each drug.

reached by 8 to 24 hours. The range of individual determinations was 3.4 to $8.0 \mu \mathrm{g} / \mathrm{ml}$ during tests in three dogs; the coefficients of variation during tests lasting 2 weeks avèraged 15 percent.

Delivery of bretylium at 13 to $15 \mathrm{mg} / \mathrm{kg}$ per day provided mean steady state concentrations of $0.79 \mu \mathrm{g} / \mathrm{ml}$ during five experiments in four dogs (range of means, 0.39 to 1.39). These values fall within the preliminary therapeutic plasma range of 0.5 to $1.5 \mu \mathrm{g} / \mathrm{ml}$. 3,10 The range of all individual steady state values was 0.26 to $1.83 \mu \mathrm{g} / \mathrm{ml}$. In vitro delivery rates, estimated to within $\pm 0.5 \mathrm{ml} /$ day, averaged $8.4( \pm 1.0) \mathrm{ml} /$ day (coefficient of variation $=12.3$ percent, for all experiments). Steady state concentrations were attained by 24 hours.

Figure 4 shows a representative experiment with bretylium in one dog. The pump is filled with bretylium tosylate on day 0 , and a rapid rise in serum drug concentration occurs over 8 hours. Steady state concentrations of $400 \pm 100 \mathrm{ng} / \mathrm{ml}$ are provided over 14 days by delivery of $8 \mathrm{ml} /$ day. After evacuation of the drug from the pump on day 14 and replacement with normal saline solution, elimination of bretylium from serum occurs over 2 to 3 days. Variations in in vivo plasma drug concentrations (coefficient of variation $=19$ percent) and flow rates (coefficient of variation $=17$ percent) were greater than variations in in vitro delivery rates (coefficient of variation $=5$ percent) but small enough to maintain constant therapeutic drug concentrations. Similar in vivo variations in determinations of partial thromboplastin time have been noted during delivery of heparin. ${ }^{7}$ Systemic effects of brety. lium were apparent in each dog, as evidenced by relaxation of the nictitating membrane of the eye, a manifestation of the sympathetic neuronal blocking effects of the drug. No other drug reactions were noted. 
FIGURE 4. In vitro delivery of bretylium shown for a representative experiment in a single dog. The plasma concentration of bretylium $(\mathrm{ng} / \mathrm{ml})$ is plotted against time (days). Arrows indicate the time of pump evacuation and refilling. NS = normal saline solution.

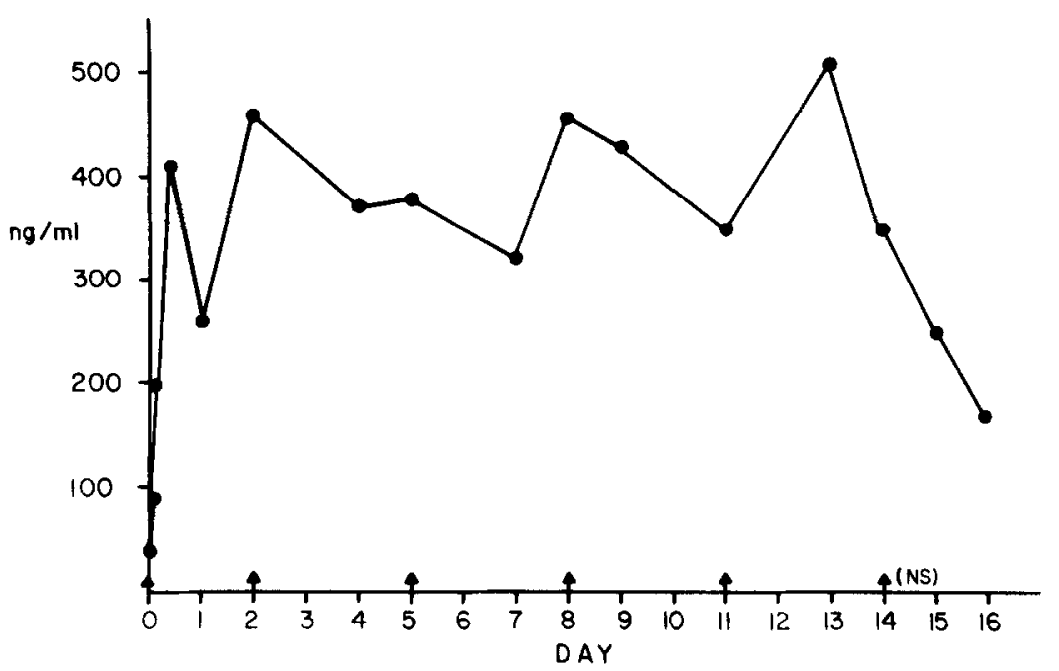

\section{Discussion}

Long-term delivery of drugs from a subcutaneous reservoir is not a new idea; however, the use of sophisticated implantable infusion devices has undergone extensive development only in recent years. ${ }^{8}$ The implantable pump used in these studies was initially designed and tested at the University of Minnesota by Blackshear and colleagues ${ }^{5,6}$ in the early 1970 s. Reliable delivery of intravenous heparin at rates of 2 to $5 \mathrm{ml} /$ day was subsequently demonstrated in dogs for periods of 1 to more than 4 years. ${ }^{7,8}$ The pump was successfully used for long-term heparin delivery in a small number of patients for periods of up to 4 years in reported trials by the same group. ${ }^{8}$ Reliable delivery of various chemotherapeutic agents selectively into the hepatic arterial system in patients with a liver tumor and into the cerebrospinal fluid in patients with advanced malignancy of the central nervous system was recently demonstrated. $8,11,12$ Other early investigational applications of the pump include delivery of insulin in diabetic patients and selective delivery of neuropharmaceutical agents. $^{8}$

Advantages: Advantages of the pump system, as suggested by this and previous studies, include: (1) total implantability, which diminishes the problems of infection and disruption present with partially implanted units; (2) a permanent, nondepletable natural (thermal) power system; (3) simple refilling requirements; (4) relatively large reservoir capacities; and (5) compatibility with a large number of drugs. The future integration of a sensing circuit and programmable flow-rate systems with the delivery pump should further increase the sophistication and utility of this and other pump systems currently under development.

Application to antiarrhythmic drug administration: New approaches to antiarrhythmic therapy are needed to reduce the incidence of sudden cardiac death. ${ }^{13}$ In part, failure of antiarrhythmic therapy is due to failure to deliver effective agents reliably and continuously. Treatment with such standard agents as lidocaine, procainamide and bretylium is limited by their specific pharmacodynamic properties. ${ }^{1,2}$ Lidocaine is ineffective when given orally because of extensive first pass hepatic metabolism. Procainamide must be given every 3 to 4 hours because of its short ( 3 hour) half-life; poor patient compliance with failure of arrhythmia control commonly results. Bretylium, a potent antifibrillatory drug, appears to be of limited use as an oral agent because of poor absorption (20 percent bioavailability). ${ }^{3,4}$ The present study demonstrated a method of delivering therapeutic concentrations of bretylium and procainamide in dogs and suggests the feasibility of this technique in patients. Although therapeutic concentrations of lidocaine were not attained, they may be possible with further work, including further modification of pump materials and design to address problems of incompatibility and high drug viscosity.

The delivery of therapeutic concentrations of procainamide may prove more challenging in human beings than in dogs. Flow rates of $12 \mathrm{ml} /$ day will probably be required. This could be attained with pumps adjusted to higher flow rates, requiring refilling every 3 to 4 days. It is unlikely that solutions of procainamide more concentrated than the relatively viscous $0.5 \mathrm{~g} / \mathrm{ml}$ solution will be useful. Gradual oxidation of procainamide solution occurs with time, imparting a yellow color but without affecting the assayed concentration of the parent drug.

Of the three drugs tested, bretylium appears to be best suited for long-term pump delivery. Its high solubility and low viscosity also suggest that it may be administered to patients in even more concentrated solutions (100 to $150 \mathrm{mg} / \mathrm{ml}$ ), which should provide systemic drug levels equal to or exceeding those attained in dogs. In contrast, patients treated with oral bretylium in three-fold greater dosages $(40 \mathrm{mg} / \mathrm{kg}$ per day) attain steady state concentrations of drug of only $0.2 \mu \mathrm{g} / \mathrm{ml}$, one fourth of the therapeutic values achieved by our pump infusions.

Bretylium is indicated for acute intravenous therapy 
of malignant ventricular arrhythmias refractory to standard treatment. Currently, administration of the drug must be discontinued after 3 to 5 days for want of an effective mode of long-term therapy. Bretylium is the only currently available class III (antifibrillatory) agent approved for general use in the United States. Thus, patients who are prone to recurrence of arrhythmias that respond to bretylium may be benefited by the opportunity for effective long-term drug delivery with a totally implanted pump system.

Implications: Favorable experience with the implantable infusion pump system suggests future in- vestigations with other cardiovascular drugs. These might include selected inotropic agents, vasodilators and anticoagulant drugs, in addition to antiarrhythmic agents.

\section{Acknowledgment}

We thank Keith D. Green for secretarial help, Linda Samtoy, RN for graphics and Jerome Schultz, PhD and ChungKwan Yen for assistance with viscosity measurements. Bretylium was kindly supplied by American Critical Care, procainamide by E. R. Squibb and Sons and lidocaine by Astra Pharmaceuticals. Metal-bellows pumps were supplied by Infusaid Corporation, Sharon, Massachusetts.

\section{References}

1. Anderson JL, Harrison DC, Meffin PJ, Winkle RA. Antiarrhythmic drugs: Clinical pharmacology and therapeutic uses. Drugs 1978; 15:271-309.

2. Winkle RA, Glantz SA, Harrison DC. Pharmacologic therapy of ventricular arrhythmias. Am J Cardiol 1975;36:629-50.

3. Anderson JL, Patterson E, Wagner JG, Stewart JR, Behm HL, Lucchesl BR. Oral and intravenous bretylium disposition. Clin Pharmacol Ther 1980;28:468-77.

4. Anderson JL, Patterson E, Wagner JG, Johnson TA, Lucchesi BR, Pltt B. Clinical pharmacokinetics of intravenous and oral bretylium tosylate in survivors of ventricular tachycardia or fibrillation: clinical application of a new assay for bretylium. J Cardiovasc Pharmacol 1981;3:485-99.

5. Blackshear PJ, Dorman FD, Blackshear PL, Varco RL, Buchwald H. A permanently implantable, self-recycling, low-flow, constant-rate, multipurpose infusion pump of simple design. Surg Forum 1970;21:136-7.

6. Blackshear PJ, Dorman FD, Blackshear PL, Varco RL, Buchwald H. The design and initial testing of an implantable infusion pump. Surg Gynecol Obstet 1972;134:51-6.

7. Blackshear PJ, Rohde TD, Varco RL, Buchwald H. One year of continuous heparinization in the dog using a totally implantable infusion pump. Surg Gynecol Obstet 1975;141:176-86

8. Blackshear PJ. Implantable drug-delivery systems. Sci Am 1979;Dec:66-73.

9. Patterson E, Stetson P, Lucchesi BR. Sensitive gas chromatographic assay for the quantitation of bretylium in plasma, urine, and myocardial tissue. J Chromatogr 1980;181:33-9.

10. Helssenbuttel RH, Bigger JT. Bretylium tosylate: a newly available antiarrhythmic drug for ventricular arrhythmias. Am Intern Med 1979;91:229-38.

11. Ensminger W, Niederhuber J, Thrall J, Belerwalters W. Hepatic arterial chemotherapy using a totally implanted drug delivery system (abstr). Clinical Investigations, American Association for Cancer Research 1980;21:596.

12. DakhlI S, Ensminger W, Kindt G. Maintenance of constant cerebrospinal fluid methotrexate levels with a totally implanted infusion system (abstr). Clinical Investigations, American Asociation for Cancer Research, 1980;21:149.

13. Lown B. Sudden cardiac death: the major challenge confronting contemporary cardiology. Am J Cardiol 1979;43:313-28. 